\title{
Tithonia diversifolia, Cyperus rotundus and Hyptis suaveloensis ethanol extracts combinatorially and competitively inhibit affinity purified cowpea storage bruchid (Callosobrochus maculatus) glutathione S-transferase
}

\author{
Ayodele O. Kolawole $\cdot$ Raphael E. Okonji . \\ Joshua O. Ajele
}

Received: 6 August 2010/Accepted: 30 January 2011/Published online: 30 March 2011

(C) The Author(s) 2011. This article is published with open access at Springerlink.com

\begin{abstract}
Ethanol extracts of Tithonia diversifolia, Cyperus rotundus and Hyptis suaveloensis have earlier been reported to have insecticidal activity against storage bruchid (Callosbrochus maculatus) reared on cowpea (Vigna unguiculata). Here, antioxidant capacities of the ethanol extracts of these plants were evaluated by determining their effects on DPPH radical scavenging, lipid peroxidation and their total phenolic contents. These extracts were further investigated for their influence on the activity of uncharacterized but purified C. maculatus glutathione S-transferases. The antioxidant properties, as a factor of total phenols and reducing power, are $0.026,0.043 ; 0.21,0.040 ; 0.15$, $0.034 \mathrm{mg} / \mathrm{ml}$ for $T$. diversifolia, C. rotundus and H. suaveloensis, respectively. Using 1-chloro-2,4-dintrobenzene (CDNB) as substrate, the GST activity was inhibited in a concentration depedent manner with $50 \%$ inhibition concentration $\left(\mathrm{IC}_{50}\right)$ of $87.8,95.4$ and $115.8 \mu \mathrm{g} / \mathrm{ml}$ for $T$. diversifolia, $C$. rotundus and $H$. suaveloensis, respectively. When compared with standard GSTs inhibitors, the order of inhibition was cibracon blue $>$ triphenyltinchloride $>$ hematin $>T$. diversifolia $>$ tributyltin acetate $>C$. rotundus $>H$. suaveloensis $>$ ethacrynic acid. These extracts bind competitively to both the active site and the hydrophobic binding site of the enzyme as presented by the Dixon
\end{abstract}

Handling Editor: Chen-Zhu Wang.

A. O. Kolawole $(\bowtie) \cdot$ J. O. Ajele

Department of Biochemistry, Federal University of Technology,

Akure, Nigeria

e-mail: maok210@yahoo.com

R. E. Okonji

Department of Biochemistry, Obafemi Awolowo University, Ile-Ife, Nigeria and Scatchard plots. Displacement of the fluorescent probe, 1-anilino-8-naphthalenesulfonate, tryptophan quenching and spectral changes induced by the plant extracts binding demonstrated a common high affinity site for which the plant secondary metabolites bind. The combinatorial competitive inhibitory approach of these plant polyphenols might contribute to the insecticidal activity against $C$. maculatus.

Keywords Cowpea storage bruchid - Enzyme inhibition glutathione S-transferases · Plant extracts · Fluorescence

\section{Introduction}

Cowpea, Vigna unguiculata L. (Walp) is an important crop in tropical countries, especially in West Africa, where it is a cheap source of dietary protein (Boeke et al. 2004b). Cowpea storage bruchid Callosobruchus maculatus (Fabr.) (Coleoptera: Bruchidae) depredates stored cowpea (Jackai and Adalla 1997). The huge post harvest losses and quality deterioration caused by this insect are major problems of assuring food security in developing countries like Nigeria (Boeke et al. 2004b). Effective control of storage insect pests are centered mainly on the use of synthetic insecticides. The continuous use of these synthetic chemicals pose problems: development of resistant insect strains, toxic residues in foods and humans; workers' safety, and high cost of procurements (Adedire 2003). These problems have necessisated research on the use of alternative, eco-friendly insect pest control methods, amongst which are the use of plant products as bioinsecticides. Boeke et al. (2004a) reported that plant materials and traditional methods are much safer than insecticides, and suggested that their use needed further exploration. The effects of some plants extracts on the biological parameters of the herbivourous 
insects (e.g. oviposition, mortality rate, adult emergence, developmental rate, mortality, fecudity and egg viablity) has been reported (Boeke et al. 2001). Earlier studies by Adedire and Lajide (1999) and Adedire and Akinneye (2003) showed that powdery and ethanol extracts of Tithonia diversifolia (Tree marigold), Cyperus rotundus (Tigernut), Hyptis suaveloensis (Labiatae) and Aframomum melegueta (Alligator pepper) have insecticidal activity against the cowpea storage bruchid, $C$. maculatus F. Understanding the diversity of the insect response to these plant powders and ethanol extracts in their local ecological context has been an important aspect of the bruchid control strategies and represents a key challenge in developing durable pest control. The responses include contact and ingestion avoidance, excretion, sequestration, degradation of the toxin and targets site mutation. Those ingested and absorbed enter the general circulation and can get accumulated into various tissues and organs (Despres et al. 2007). Their accumulation in tissues and organs can have severe physiological consequences such as cyst lesions, metabolic acidosis, and death (Valko et al. 2006). The responses of the insects to the plant secondary metabolites have been informative models for studying molecular mechanisms of resistance.

Secondary metabolites of many plants have diverse biological and pharmacological effects including inhibition and induction of several enzymes. The glutathione S-transferases (GSTs; EC 2.5.1.18) family has been involved in the detoxification of various plant xenobiotics (Francis et al. 2005). It can be induced by the administration of various plant secondary metabolites and ultimately confer resistance to metabolites. Although GST enzymes can be involved in substrate sequestration, they usually catalyze the conjugation of glutathione to electrophilic toxic molecules, increasing their solubility and facilitating their elimination by the insects (Enayati et al. 2005). The role of GSTs in the resistance to plant chemicals has been studied in numerous crop-feeding lepidopteran species and in insects feeding on deciduous trees (Yu 1996). Fakae et al. (2000) has tested Piliostigma tholnningii, Ocimum gratissium, Nauclea latifolia and Alstonia boonei against gastrointestinal helminthes of animals and man. The nematodes' glutathione S-transferases are a potential drug target, and inhibitory properties of these plant extracts against the GST may have been the pharmacological basis of their efficacy.

Currently, comprehensive reports on glutathione S- transferases of cowpea storage bruchid (Callosobruchus maculatus) are lacking. This work is aimed at investigating the pharmacological basis of the efficacy of ethanol extracts of $T$. diversifolia, $C$. rotundus and $H$. suaveloensis against cowpea storage bruchid glutathione S-transferase. This study describs the isolation and purification of glutathione
S-transferases from cowpea storage bruchid, and the inhibition of the GST activity in vitro by the plant ethanol extracts.

\section{Materials and methods}

Glutathione, phenyl methanesulfonyl fluoride (PMSF) and 2,2-diphenyl-1-picrylhydrazyl (DPPH) were from Sigma Chemical Company, St. Louis, USA; 1-chloro-2, 4-dinitrobenzene and 8-anilinonaphthalene-1-sulphonate (ANS) were purchased from Aldrich Chemicals, USA. Glutathione-Sepharose 4B was from Armersham Pharmacia, Uppsala, Sweden. Folin- Ciocateu's phenol Reagent $2 \mathrm{~N}$ was from LOBA Chemie, Mumbai, India. Ethanol, Trichloracetic acid, potassium ferrocyanide was from Qualigen Fine Chemicals, Mumbai, India. Other reagents used were of analytical grade and water used was Milli Q. Unless otherwise stated, the ethanol used was double distilled.

Preparation of plant extracts

Fresh leaves of $T$. diversifolia, $C$. rotundus and $H$. suaveloensis were collected from a piece of land at Federal University of Technology, Akure, Nigeria. The leaves were later taken to the Crop Production Department of the University for botanical identification. The plant extracts were prepared as described earlier (Adedire and Akinneye 2003) with slight modification. Two hundred grams $(200 \mathrm{~g})$ of each sample was air-dried, and ground with Waring type stainless steel commercial blender. Chemical extraction was carried out in Heidolph Laborata 4000 rotary evaporator at $50^{\circ} \mathrm{C}$ using $95 \%$ absolute ethanol as solvent. Extracts were then filtered through Whatman No 1 filter paper and the clear supernatant was freeze dried and stored at $4^{\circ} \mathrm{C}$ prior to the toxicity bioassays on GST.

\section{Phytochemical screening}

The ethanol extract was screened for the presence of secondary metabolites such as alkaloids, saponin, steroids, cardiac glycoside, tannins and flavonoids following the methods described elsewhere (Sofowora 1993).

Total phenol

The concentrations of phenolic compounds in the ethanol extracts are expressed as tannin equivalents, and were measured using a method from Singleton et al. (1999) with some modifications. Ethanol extract $(0.1 \mathrm{~g})$ was dissolved in $5 \mathrm{ml}$ of acetone for $10 \mathrm{~min}$ on ice. To $0.5 \mathrm{ml}$ of the solution, $0.5 \mathrm{ml}$ of distilled water, $0.5 \mathrm{ml}$ of Folin- Ciocateu's phenol Reagent 2 N (1: 1) and $2.5 \mathrm{ml}$ of $20 \%$ 
sodium carbonate were added. The reaction mixtures were kept in the dark for $40 \mathrm{~min}$, after which the absorbance was read at $750 \mathrm{~nm}$. Phenol contents were extrapolated from standard tannin calibration curve.

\section{Reducing property}

The ability of ethanol extracts to reduce ferric chloride was measured according to a modified method of Pulido et al. (2000). The reducing property was expressed as tocopherol (Vitamin E) equivalent. The ethanol extracts $(5 \mathrm{~g})$ were dissolved in $10 \mathrm{ml}$ of water and filtered. To $2.5 \mathrm{ml}$ of the filtrate, $2.5 \mathrm{ml}$ of phosphate buffer ( $\mathrm{pH} 6.6)$ and $2.5 \mathrm{ml}$ of potassium ferrocyanide were added. The mixture was incubated at a temperature of $40^{\circ} \mathrm{C}$. After incubating, $10 \%$ trichloroacetic acid was added. The resulting mixtures were centrifuged for $10 \mathrm{~min}$. The supernatant $(5 \mathrm{ml})$ was mixed with $5 \mathrm{ml}$ of distilled water and $1.0 \mathrm{ml}$ of $0.1 \%$ ferric chloride. The absorbance of the standard and the sample were read at $700 \mathrm{~nm}$ against reagent blank made of ethanol instead of ethanol extract.

Free radical scavenging

The scavenging activity of the Vitamin $\mathrm{E}$ and $T$. diversifolia, $C$. rotundus and $H$. suaveloensis ethanol leaf extract on DPPH radicals were determined as described elsewhere (Chu et al. 2000). An aliquot of $0.5 \mathrm{ml}$ of $0.1 \mathrm{mM}$ DPPH radical in ethanol was added to test tubes containing $1 \mathrm{ml}$ of different concentrations $(0-5 \mathrm{mg} / \mathrm{ml})$ of the ethanol extract. The reaction mixture was mixed at room temperature and kept for $20 \mathrm{~min}$. The absorbance was read at $520 \mathrm{~nm}$ against distilled water. Radical scavenging capacity of each extract has been calculated as the percent DPPH radical scavenging effect which is:

DPPH Scavenging Effect $(\%)=\left(\left[\mathrm{A}_{\mathrm{o}}-\mathrm{A}_{\mathrm{i}}\right)\right] / \mathrm{A}_{\mathrm{o}} \times 100$

where $A_{o}$ is the absorbance of the control with ethanol and $A_{1}$ is the absorbance of the sample in the presence of the extracts.

\section{Purification of GST}

Callosobrochus maculatus adults were obtained from naturally infested cowpea seeds (Sokoto white cultivar of cowpea) from Oba Market in Akure, Nigeria. The whole organism was homogenized in a buffer $(10 \mathrm{mM}$ Tris-HCl, $250 \mathrm{mM}$ sucrose, $1 \mathrm{mM}$ phenylmethanesulfonyl fluoride, $0.1 \mathrm{mM} \beta$-mecrapoethanol, $\mathrm{pH} 7.4$ ) and centrifuged at $30,000 \mathrm{~g}$ for $40 \mathrm{~min}$ to remove cell debris using Eppendorf cold centrifuge $5810 \mathrm{R}$. The supernatant was rapidly purified on GSH-Sepharose 4B column as earlier described by Kolawole and Ajele (2004). The GST was ultra filtrated with 5,000 M.W. cut off filter of Amicon Ultra-4 (Millipore Co., USA). Purity of the enzyme was established by denaturating polyacrylamide gel electrophoresis (SDSPAGE) using a 5\% staking gel overlaid on a $12 \%$ resolving gel. The gels were stained by Coomasie brilliant blue $\mathrm{R}-250$. The enzyme could be stored at $-70^{\circ} \mathrm{C}$ until used.

Determination of protein concentration and glutathione S-transferases assay

GST activity was determined according to Habig et al. (1974) as modified by Ajele and Afolayan (1992). For a typical assay, the reaction mixture of $3.0 \mathrm{ml}$ containing a final concentration of $100 \mathrm{mM}$ potassium phosphate buffer $\mathrm{pH} \quad 6.5$ and $1.0 \mathrm{mM}$ glutathione $(\mathrm{GSH})$ and $1.0 \mathrm{mM}$ 1-chloro-2, 4-dinitrobenzene (CDNB), together with an appropriate amount of enzyme. Three replicates were used for each measure. One unit of GSTs activity is defined as the amount of enzyme producing 1 mol thioether per min. The extinction coefficient for CDNB conjugate at $340 \mathrm{~nm}$ is $0.0096 \mu \mathrm{M}^{-1} \mathrm{~cm}^{-1}$. A Shimadzu UV-Visible 1601 double beam digital spectrophotometer was used for the assay. The kinetic analysis of inhibition and type of inhibition was done by adding known concentrations of plant extracts to the assay buffer prior to assay. The concentration of the extract resulting from $50 \%$ inhibition $\left(\mathrm{IC}_{50}\right)$ was determined from a plot of remaining activity versus the extract concentration. Dixon plot, a plot of series of straight lines of reciprocal velocity $(1 / \mathrm{V})$ versus inhibitor concentration, was used to establish the type of inhibition mechanism.

The protein concentration was determined by Bradford Method (Bradford 1976). Two replicates were used for each experiments using bovine serum albumin as a standard.

\section{Fluorescence spectroscopy}

All the fluorescence spectra were recorded on a Hitachi F-4500 Spectrofluorometer. The widths of both the excitation and emission slit were at $5 \mathrm{~nm}$ bandwidth. ANS (1-anilino-8-naphthalene-sulfonate) is an extrinsic fluorescence probe that binds to the hydrophobic patches present on a protein surface. To investigate the interaction between the GST and the ethanol plant extracts by competitive fluorescence spectroscopy, the inhibition of ANS bound GST was monitored by following the decrease in the fluorescence of ANS. Assays were carried out in $2 \mathrm{ml}$ volume that contained $10 \mathrm{mM}$ phosphate buffer, $\mathrm{pH} 6.5,30 \mu \mathrm{M}$ ANS, $0.43 \mu \mathrm{g} / \mu \mathrm{l}$ GST. Changes in the relative fluorescence of the ANSenzyme complex over a range of ethanol extracts concentration of $T$. diversifolia, $C$. rotundus and $H$. suaveloensis. The ethanol extract was added to a final volume of $10 \mu \mathrm{l}$ at $2 \mu \mathrm{l}$ aliquots. The solution was mixed after each addition and fluorescence was measured at $480 \mathrm{~nm}$ after excitation at 
$360 \mathrm{~nm}$ (at room temperature). Changes in relative fluorescence of the ANS-enzyme complex were recorded over a range of extract concentrations. To determine the type of inhibition, the concentration of ANS was varied between 5 and $80 \mu \mathrm{M}$ while the concentration of GST $(0.43 \mu \mathrm{g} / \mu \mathrm{l})$ and plant extracts $(150 \mu \mathrm{g} / \mathrm{ml})$ were kept constant. The Scatchard plot was used to determine the type of inhibition and the apparent dissociation constant $\left(K_{\mathrm{d}}\right)$ were calculated. Also, the decrease in intrinsic fluorescence intensity at $\lambda \max$ was analyzed according to the Stern-Volmer equation:

$\mathrm{F}_{\mathrm{O}} / \mathrm{F}=1+\mathrm{K}_{\mathrm{SV}}[\mathrm{Q}]$

where $F_{0}$ and $F$ are the fluorescence intensities at an appropriate wavelength in the absence and presence of quencher, respectively; $\mathrm{K}_{\mathrm{SV}}$ is the Stern-Volmer constant; and $[\mathrm{Q}]$ is concentration of the quencher.

\section{Statistics}

The results are presented as mean values \pm standard error (SEM). Student's $t$-test for significant differences was used to compare groups. Where appropriate, data were compared by a one-way analysis of variance (ANOVA). Least squares linear regression analysis and the correlation coefficient, $r$, given as appropriate, tested the relationship (rectilinear) between two variables. Differences were considered significantly different at $P<0.05$.

\section{Results}

Phytochemical screening

The result of the phytochemical screening of $T$. diversifolia, H. suaveloensis and C. rotundus is shown in Table 1 . Ethanol extract of $T$. diversifolia showed the presence of alkaloids, saponin, steroids, cardiac glycoside, tannin and flavonoid. The tannin and alkaloid contents are high. T. diversifolia has higher phytochemical content comapred to $C$. rotundus and $H$. suaveloensis.

\section{Antioxidant properties}

The antioxidant properties of $T$. diversifolia, $C$. rotundus and $H$. suaveloensis as revealed by total phenol content was
$0.26 \pm 0.01, \quad 0.21 \pm 0.007$ and $\quad 0.15 \pm 0.01 \mathrm{mg} / \mathrm{ml}$, respectively as tannin equivqlents (Table 2 ). The results are expressed as $\mathrm{mg}$ of total phenolics in $\mathrm{mg}$ of extract. T. diversifolia, $C$. rotundus and $H$. suaveloensis has reducing properties level of $0.043,0.040$ and $0.034 \mathrm{mg} / \mathrm{ml}$, respectively. $\alpha$-tocopherol, a well-known antioxidant, was used as a standard in this study. The reducing property was $0.039 \mathrm{mg} / \mathrm{ml}$. Compared with the extracts. T. diversifolia, C. rotundus have higher reducing properties than $\alpha$-tocopherol. DPPH (1, 1-diphenyl-2-picrylhydrazyl) percent scavenging activities of the plants were measured in different concentrations ranging from 0 to $5 \mathrm{mg} / \mathrm{ml}$. The DPPH method is the direct method used to evaluate the real-time free radical scvaneging. A $5 \mathrm{mg} / \mathrm{ml}$ of $T$. diversifolia showed $60 \%$ inhibtion; $C$. rotundus, $53 \%$, and $H$. suaveloensis, $44 \%$ inhibition as shown in Fig. 1. Among the plants studied T. diversifolia exerted the highest antioxidant activity as shown in the total phenolic content, reducing properties, and DPPH radical scavenging capacities. $H$. suaveloensis showed the lowest capacities among the three plants studied.

\section{Effect of the plant extracts on Callosobrochus maculatus GST}

The SDS-PAGE analysis of the purified GST revealed a single band, suggesting that the enzyme is pure (Fig. 2). The molecular mass of the GST as indicated was $25 \mathrm{kDa}$. The extracts inhibited the GST activity dose-dependently with $50 \%$ inhibition concentration $\left(\mathrm{IC}_{50}\right)$ of $87.8,95.4$ and $115.8 \mu \mathrm{g} / \mathrm{ml}$ for $T$. diversifolia, C. rotundus and H. suaveloensis, respectively. To obtain information on the nature of inhibition of the purified GST by the extracts, Dixon plot was used. Here, a series of straight lines was observed, which intersect each other above the horizontal axis in the left hand upper quadrant (Fig. 3a-c). These reflect competitive inhibition (Dixon and Webb 1979). The $K_{\mathrm{i}}$ values obtained from the plot are 84, 160 and $210 \mu \mathrm{g} / \mathrm{ml}$, respectively, for $T$. diversifolia, $C$. rotundus and $H$. suaveloensis (Fig. 3a-c). Finally, we compare the the $\mathrm{IC}_{50}$ of these ethanol plant extracts with some known GST inhibitors. Their $\mathrm{IC}_{50}$ of cibracron blue, triphenyltinchloride, hematin, tributyltin acetate, ethacrynic acid values are 22, 80, 91 and $217 \mu \mathrm{g} / \mathrm{ml}$, respectively. Therefore, the order of inhibition as shown by graphical calculation of $\mathrm{IC}_{50}$ is cibracon blue $>$ triphenyltinchloride $>$ hematin $>T$. diversifolia $>$

Table 1 Plants used for insecticidal activity and phytochemical components

\begin{tabular}{|c|c|c|c|c|c|c|c|}
\hline Plants & Plant part used & Alkaloid & Saponin & Cardiac glycoside & Tannin & Steroids & Flavonoids \\
\hline T. diversifolia & Leaves & +++ & ++ & + & +++ & + & ++ \\
\hline C. rotundus & Roots & + & + & - & + & - & + \\
\hline H. suaveloensis & Leaves & ++ & ++ & + & + & - & ++ \\
\hline
\end{tabular}

Keys: “+” present, “-” Absent 
Table 2 Antioxidant activities of the plants extracts

\begin{tabular}{lllr}
\hline Plants & Total phenols $(\mathrm{mg} / \mathrm{ml})$ & Reducing properties $(\mathrm{mg} / \mathrm{ml})$ & GST inhibition IC \\
\hline T. diversifolia & $(\mu \mathrm{g} / \mathrm{ml})$ \\
C. rotundus & $0.26 \pm 0.010$ & $0.043 \pm 0.01$ & $87.8 \pm 1.4$ \\
H. suaveloensis & $0.21 \pm 0.007$ & $0.040 \pm 0.01$ & $95.4 \pm 1.8$ \\
$\alpha$-tocopherol & $0.15 \pm 0.002$ & $0.034 \pm 0.02$ & $115.8 \pm 2.0$ \\
\hline
\end{tabular}

Values are means \pm SD of three determinations. $t$ values $>0.05$ are not significantly different at $5 \%$ probability level

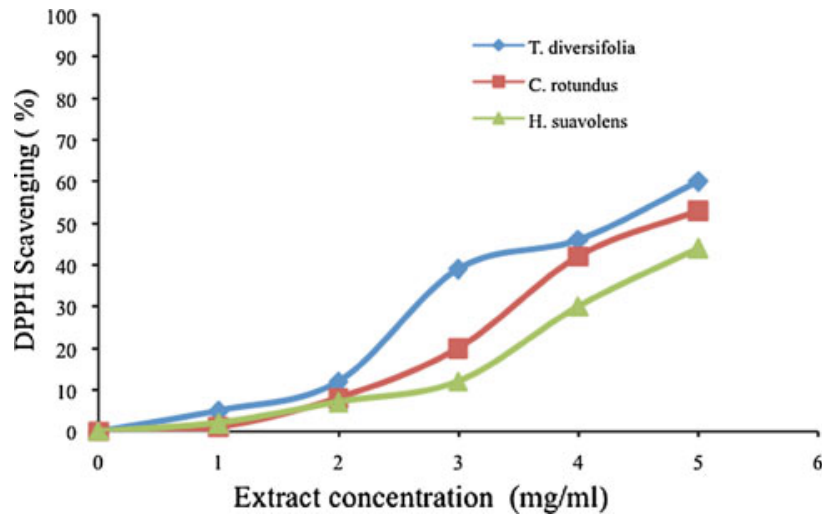

Fig. 1 DPPH scavenging activities abilities of the plant extracts

tributyltin acetate $>C . \quad$ rotundus $>H . \quad$ suaveloensis $>$ ethacrynic acid.

\section{Fluorescence spectroscopy spectra}

The addition of the various plant extracts decreases the fluorescence of ANS in a concentration dependent manner (Fig. 4). The addition of the plant extracts resulted in the quenching of the fluorescence, then the protein also binds to those secondary metabolites in the plant extracts. T. diversifolia caused the most decrease in flouresnece intensity. These results indicate that the secondary metabolites in the plant extract binds to the enzyme's molecule inhibiting the binding of ANS to the enzyme.

Scatchard plot was used to explain the pattern of the inhibition of the binding of ANS and T. diversifolia, C. rotundus and $H$. suaveloensis with hydrophobic binding site of glutathione S-transferase from $C$. maculatus, in vitro. It also demonstrates the competitive nature of the inhibition when the concentrations of ANS were varied in the presence and absence of the plant extracts (Fig. 5). A decrease in the intrinsic GST fluorescence $\left(\lambda_{\max }=345 \mathrm{~nm}\right)$ intensity due to the quenching with the addition of ethanol extract of $T$. $d i$ versifolia, $C$. rotundus and $H$. suaveloensis was observed and the emission spectrum did not undergo any visible shift (Fig. 6a-c). In order to confirm the quenching mechanism of GST upon the interaction with ethanol extract of $T$. diversifolia, $C$. rotundus and $H$. suaveloensis. The Stern-Volmer

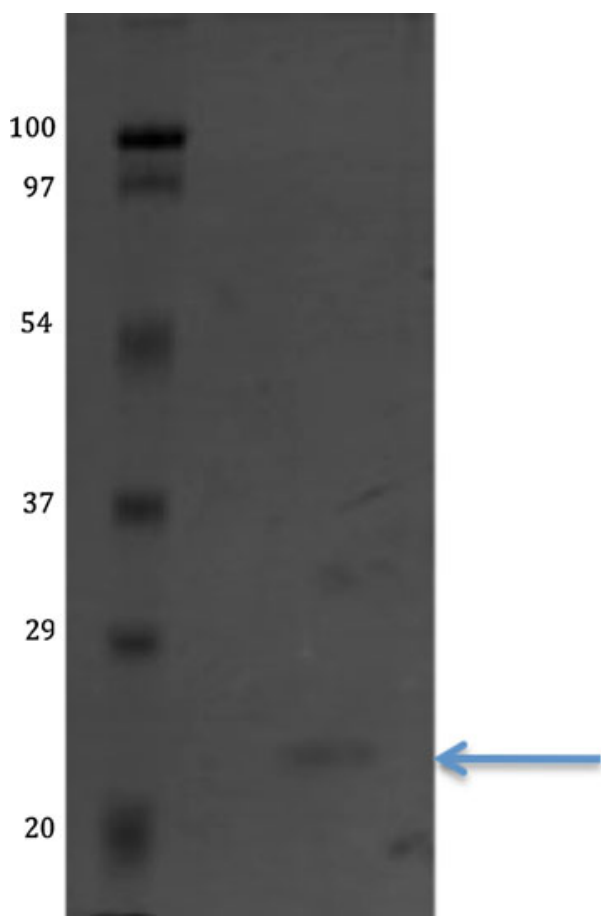

Fig. 2 SDS-PAGE of purified GST from C. maculatus. (Lane 1: Standard proteins Lane 2: purified GST). Analysis was performed on gel containing $12 \%$ plyacrylamide. Electrophoresis was performed for $3 \mathrm{~h}$ at $60 \mathrm{~V}$ at room temperature. Protein bands were visualised by Coomasie brilliant blue R-250)

plot was used showing the quenching of tryptophan at $\mathrm{pH} 6.5$ (Fig. 7). The Stern-Volmer constant $K_{\mathrm{SV}}$ values are 0.013 , 0.004 and $0.002 \mathrm{M}$, respectively. A high $K_{\mathrm{sv}}$ value was obtained for $T$. diversifolia compared with $C$. rotundus and H. Suaveloensis.

\section{Discussion}

The use of plant products to protect stored cowpea, Vigna unguiculata L. (Walp) against cowpea storage bruchid (C. maculatus) predation is an age-old practice in Nigeria (Lale 1992). The ethanol extract of $T$. diversifolia, C. rotundus and $H$. suaveloensis has earlier been reported to have potent insecticidal activity against cowpea storage bruchid ( $C$ maculatus F.). These plants have different 
Fig. 3 a Dixon Plot of the reciprocal of GST activity (1/V) versus $T$. diversifolia

concentration utilizing 1.0, 1.5 and $2.0 \mathrm{mM} \mathrm{CDNB}$

concentrations. Lines of best fit were determined by least square linear regression analysis.

b Dixon Plot of the reciprocal of GST activity $(1 / \mathrm{V})$ versus $H$ suaveloensis concentration utilizing 1.0, 1.5 and $2.0 \mathrm{mM}$ CDNB concentrations. Lines of best fit were determined by least square linear regression analysis. c Dixon Plot of the reciprocal of GST activity (1/V) versus $C$ rotundus concentration utilizing 1.0, 1.5 and $2.0 \mathrm{mM}$ CDNB concentrations. Lines of best fit were determined by least square linear regression analysis a

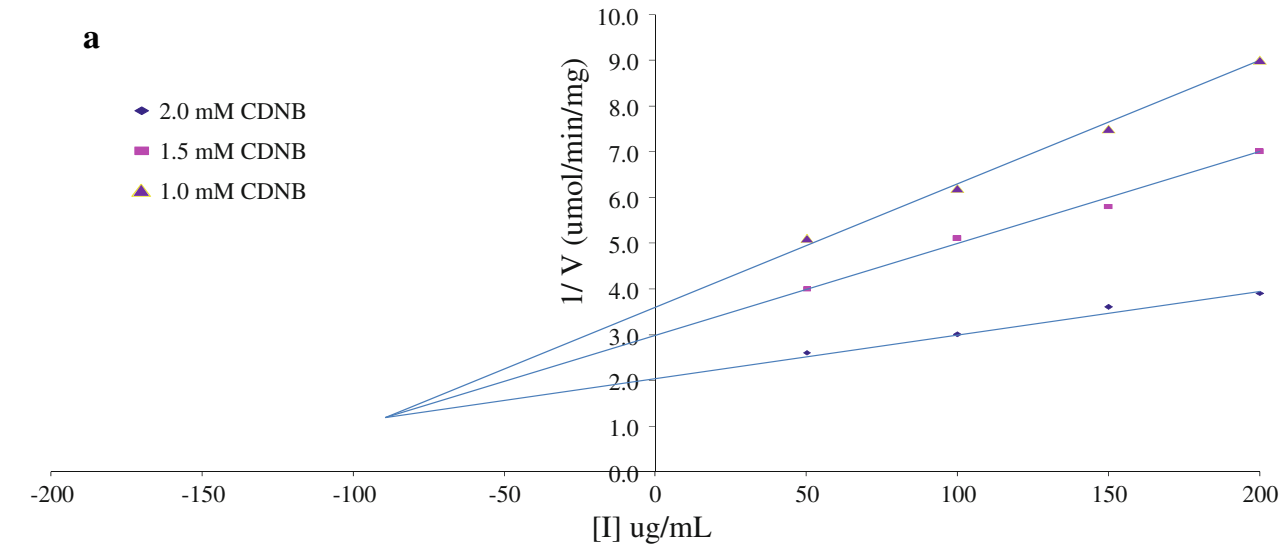

b

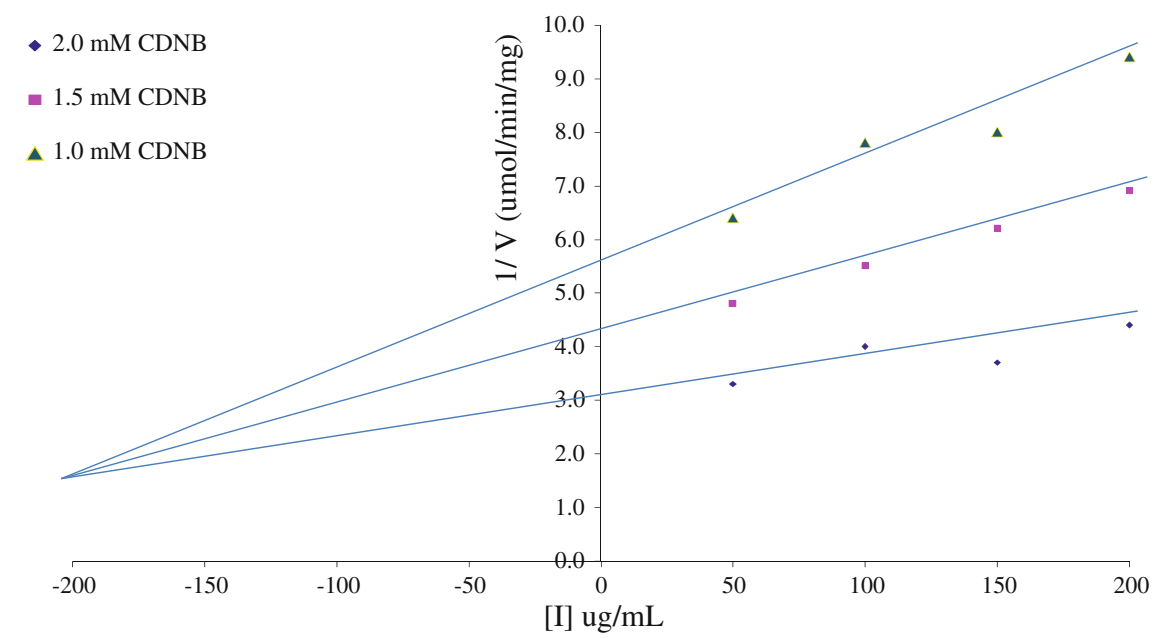

c

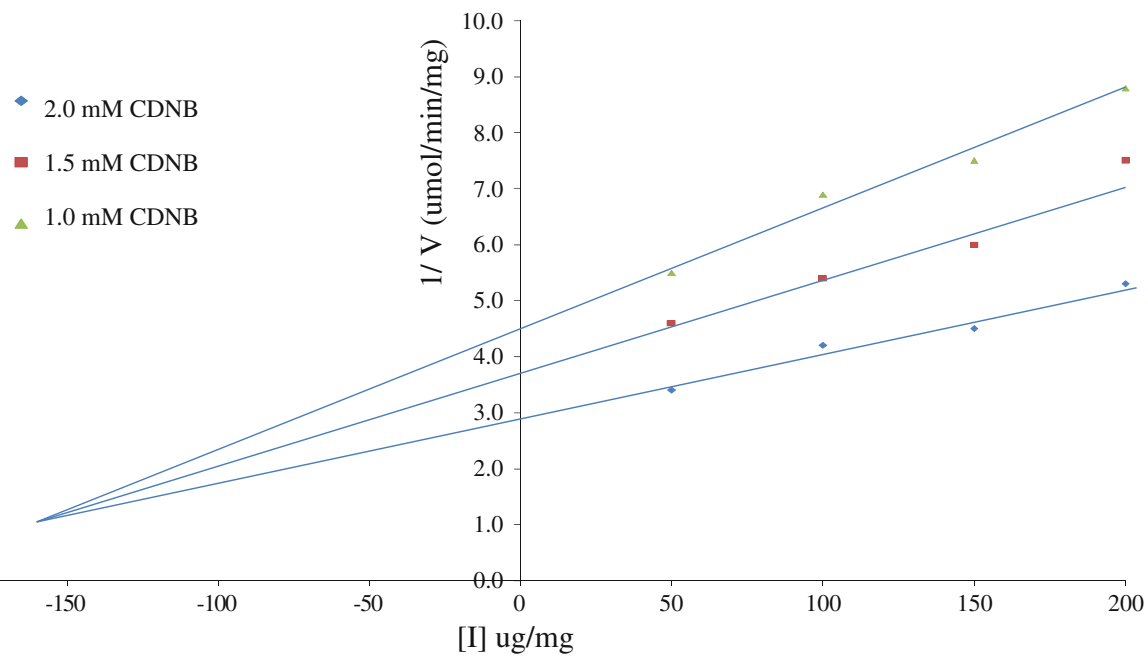

degree of insecticidal potential against the insects (Adedire and Lajide 1999; Adedire and Akinneye 2003). Boeke et al. (2004a) have reported, extensively, on plant extracts that have some effect on the development and behaviour of C. maculatus.

In this study, our aim was to collect information on the possible molecular basis for the efficacy of these plant extracts in the effective management of cowpea storage bruchids as earlier reported. The plant extracts were first screened for the bioactive components that could be responsible for the efficacy. Our results show the presence of alkaloids, saponin, tannins and flavonoids as the major phytochemicals of these plants extracts. The extract did not show the appreciable presence of cardiac glycoside and 


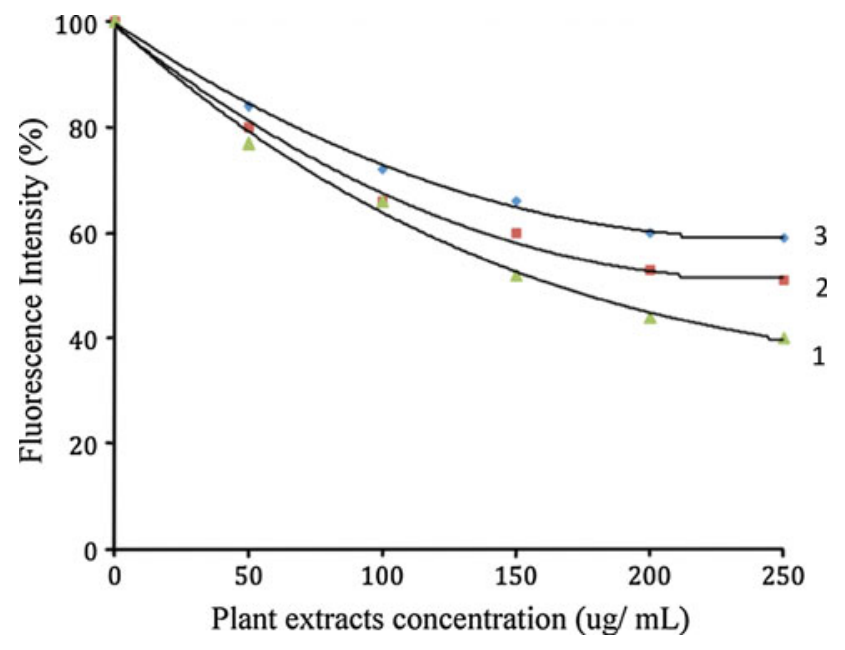

Fig. 4 Inhibition of the binding of ANS (Fluorescence Intensity) by various concentration of plant extracts (1) T. diversifolia, (2) C. rotundus and (3) H. suaveloensis. The concentration of ANS and GST were fixed at $30 \mu \mathrm{M}$ and $0.42 \mu \mathrm{g} / \mathrm{ml}$, respectively. $Y$ axis represent percentage intenisty of fluoresence with $100 \%$ representing that of bound ANS in the absence of inhibitor

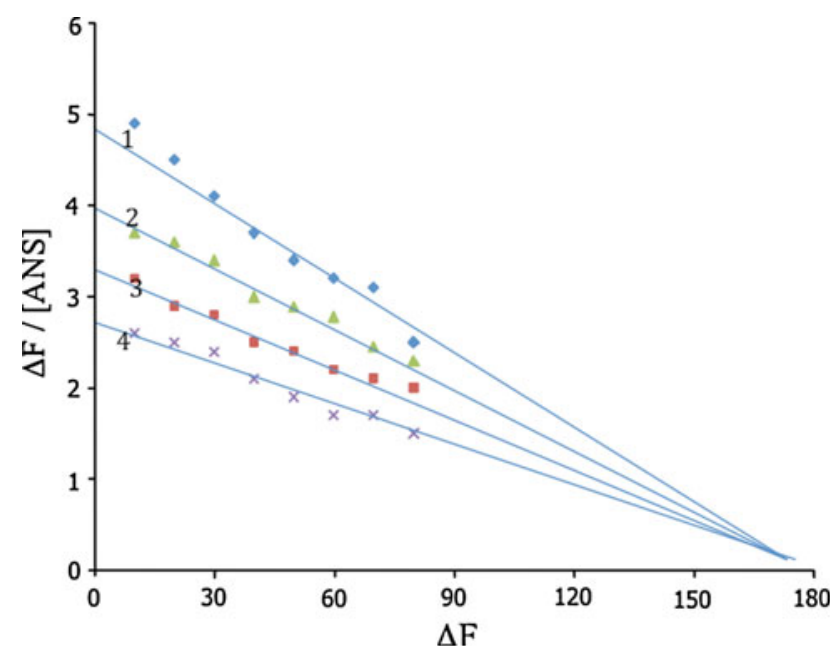

Fig. 5 Scatchard plot of the binding of ANS to T. diversifolia, $C$. rotundus and $H$. suaveloensis extracts in the absence of (1), presence of $150 \mu \mathrm{g} / \mathrm{ml}$ of $T$. diversifolia (4), C. rotundus (3) and $H$. suaveloensis (2). The concentration of ANS was varied from 5 to $80 \mu \mathrm{M}$ while the concentration of GST was held to $0.42 \mu \mathrm{g} / \mathrm{ml}$. The binding of ANS was determined by the change in the fluoresence $(\Delta \mathrm{F})$

steroid. These various phytochemical compounds detected are known to have beneficial use in industries and medical sciences (Ngbede et al. 2008).

These plant extracts have high content of polyphenols and antioxidant activity as shown in our results when compared with $\alpha$-tocopherol. The high antioxidant activity and reducing properties could be attributed to respective content of secondary metabolites in the extracts. H. suaveloensis has the lowest content of secondary metabolites and is the least effective antioxidant plant among the three
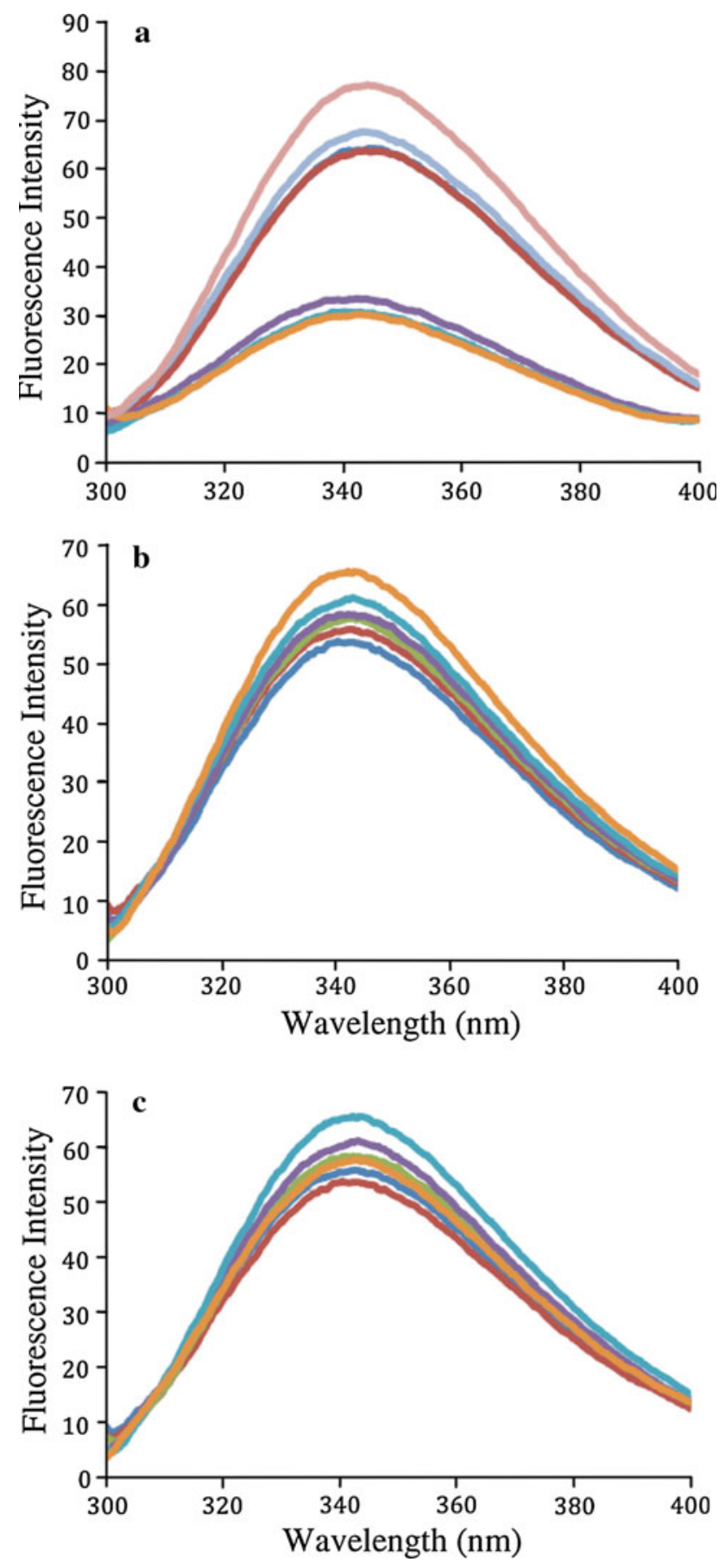

Fig. 6 Fluoresence spectra of GST on addition of different concentration of a $T$. diversifolia $\mathbf{b} C$. rotundus and $\mathbf{c} H$. suaveloensis $(\mathrm{T}=298 \mathrm{~K} \lambda=295 \mathrm{~nm}, \mathrm{pH} 6.5 \mathrm{GST}$ concnetration $=0.42 \mu \mathrm{g} / \mathrm{ml})$

plants studied. Phenolic constituents have been studied extensively as important contributors to the antioxidant activity in plants (Aruoma 2003; Skerget et al. 2005). It has been reported that the total phenolic content of a plant extract are correlated to its antioxidant activity (Coruh et al. 2007a). In the present study, as shown in Table 1 the extract with high phenolic content, also has high DPPH 


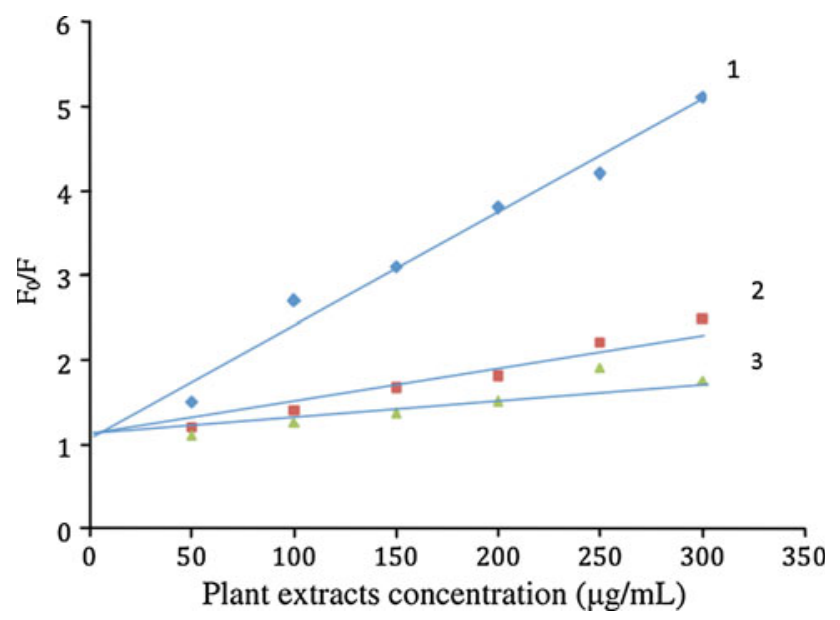

Fig. 7 Stern-Volmer plots showing the GST tryptophan quenching by $T$. diversifolia (1), $C$. rotundus (2) and $H$. suaveloensis (3). The Stern Volmer constant $\left(K_{\mathrm{sv}}\right)$ are $0.013,0.004$ and $0.02 \mathrm{M}$, respectively. $\mathrm{F}$ is the change in the fluoresence and $\mathrm{F}_{\mathrm{o}}$ is the intial fluoresence

radical scavenging. The mode of antioxidant might involve radical scavenging, anti-superoxide formation and metal chelation (Gyamfi et al. 2004). These polyphenols has diverse biological and pharmacologcial effects including inhibition and induction of several enzymes.

Our investigation shows that all the plant extracts used in this study inhibited the insect GST in a concentration dependent manner. The extract with high total phenol, reducing properties and antioxidant activity has more inhibitory effects on the glutathione S-transferases (GST) in vitro. Gyamfi et al. (2004) has earlier posited that naturally occurring plant polyphenols are potent inhibitors of GST activity. Considering the low values of the $\mathrm{IC}_{50}$ (Table 2), these extracts might be effective inhibitors of GST in vivo. We therefore investigated the inhibition mechanism on the purified sample of the GST. Our results suggest that the inhibition was competitive as shown by the Dixon plot. This indicats that these extracts bind to the active site on GST and might prevent detoxification mechanism of the enzyme. Thonningianin A, a tannin, isolated from African medicinal herb (Thonningia sanguinea) was found to be a non-competitive inhibitor to rat GST (Gyamfi et al. 2004). The authors posited further that the binding site of Thonningianin $\mathrm{A}$ is remote from the catalytic sites leading to conformational changes and hence enzyme inactivation and concluded that the biological activity and inhibition pattern of plant phytochemical is affected by its structure.

Tithonia diversifolia with highest antioxidant and DPPH scavenging abilities has lowest $K_{\mathrm{I}}$ and $\mathrm{IC}_{50}$ for the GST actitivity. This evidently suggest that extract with higher naturally occuring polyphenols inhibitors are more potent GST activity inhibitors. The observation of the in vitro inhibition of cowpea storage bruchid (C. maculatus) glutathione S-transferases by the extracts of $T$. diversifolia, $C$. rotundus and $H$. suaveloensis is in agreement with the ealier report of Fakae et al. (2000) that the GST of parasitic nematodes was inhibited by some Nigerian medicinal plants. This is also supported by the later reports (Skerget et al. 2005; Coruh et al. 2007b), whose work on Gundelia tournefortii, Prangos ferulacea (L.) Lindl., Chaerophyllum macropodum Boiss and Heracleum persicum Desf. extracts showed great inhibition on glutathione-S-transferases activity of sheep liver. The inhibitory effects of naturally occurring plant polyphenols such as tannic acid, ellagic acid, ferulic acid, caffeic acid, stilbene, quercetin, curcumin and chlorogenic acid against GST have long been reported by many researchers (Coruh et al. 2007a; Kawabata et al. 2000). Quinines are also well-known examples of covalent inhibitors of GST enzymes (Zanden et al. 2004). From our results, it appears that the extracts with high polyphenols and reducing properties have effective inhibition on GST of the cowpea storage bruchid (C. maculatus). This suggests that the antioxidant activity of the polyphenols and secondary metabolites might be responsible for its bioinsecticidal role. A plant extract that is inhibitory against the insect GST may contain several coexistent secondary metabolites.

Fluorescence spectroscopy experiments was used in an attempt to evaluate whether the secondary metabolites in the plant extracts of $T$. diversifolia, $C$. rotundus and $H$. suaveloensis bound in the hydrophobic pocket of GST from the cowpea storage bruchid (C. maculatus). An ANS competition assay was used for the hydrophobic probe. ANS has been used as a fluorescent probe to monitor the interaction with hydrophobic site of several proteins. It is noteworthy that ANS bound to C. maculatus GST. Moreover, in the competition assay, plant extracts of $T$. diversifolia, $C$. rotundus and $H$. suaveloensis were able to displace bound ANS from GST by causing the quenching of ANS fluorescence. This proves the existence of a hydrophobic binding site on the $C$. maculatus GST. It further confirms the binding of the secondary metabolites onto the enzyme's hydrophobic site apart from its catalytic site. $T$. diversifolia was displaced the most in the experiment. The displacement of ANS could be the result of a conformational change in GST upon separate binding of the plant extract or the direct competition between the substances. Sugiyama et al. (1984) have also reported the competitive displacement of ANS by lithocholic acid and bilirubin from glutathione S-transferase B from rat liver. Using the Scatchard plot, there is an existence of competitive binding between ANS and secondary metabolites of the plant extract for the hydrophobic binding site.

These plant extracts induced quenching of the insect GST fluorescence. This was deduced from the decrease of 
fluorescence intensity at $347 \mathrm{~nm}$. Spectral scans were repeated to test for time-dependent effects, all samples were found to exhibit rapid equilibration. The fluorescence quenching indicates either the direct interaction of these plant polyphenols with tryptophan residues of the GST or the conformational changes induced by the plant polyphenol binding, which alters tryptophan fluorescence. The values of Stern-Volmer quenching constants $\left(K_{\mathrm{sv}}\right)$ calculated from Stern-Volmer plot for T. diversifolia, C. rotundus and $H$. suaveloensis at $\mathrm{pH} 6.5$ are $0.013,0.004$ and $0.002 \mathrm{M}$, respectively. Based on the $K_{\mathrm{sv}}$ values, $T$. diversifolia showed a more profound quenching effect. Zhang et al. (2007) has reported that tannic acid showed a more significant effect on the quenching of pig liver GST compared to cinnamic acid, rutin and catechin. They postulated that hydroxyl groups of tannic acid could be responsible for higher affinity for pig liver GST and quenching process. The linearity of the Stern-Volmer plot of the GST and the quenching process showed the existence of one binding site in the proximity of one of its tryptophan residues or more than one binding site in the proximity of one of its tryptophan residues or more than one binding site is accessible equally to the metabolites Zhang et al. (2007).

It appears that assemblage of the secondary metabolites in the plant extracts of $T$. diversifolia, $C$. rotundus and $H$. suaveloensis help exhibit multiple competitive inhibition pattern. These inhibitions may help explain the mode of action of the extracts and might account for the pharmacological basis of its efficacy in the management of C. maculatus. Fakae et al. (2000) suggested the combinatorial approach of some active allelochemicals in the plant extracts on the effective inhibition of GST. If this is true, the combinatorial competitive inhibition approach prevents either modification of the target site or an amplified production of this detoxification enzyme (Haubruge and Amichot 1995).

With these, the pharmacological basis of these plant extracts' insecticidal activity on C. maculatus might be by its inhibition mechanisms of the insect GST in vivo. The biological activity and inhibition pattern of the plant phytochemical is affected by its structure. The question still remains if the binding of these extracts brings about the cooperative binding on the other dimer. This merits a further investigation of the competitive binding assays.

Acknowledgments This research was supported by research grant No F/4449-1F from the International Foundation for Science (IFS). The authors acknowledge the support of Centre for Cellular and Molecular Biology (CCMB), Hyderabad, India.

Open Access This article is distributed under the terms of the Creative Commons Attribution Noncommercial License which permits any noncommercial use, distribution, and reproduction in any medium, provided the original author(s) and source are credited.

\section{References}

Adedire CO (2003) Use of nutmeg, Myristica fragrans (Houtt) powder and oil for the control of cowpea storage bruchids, Callosobruchus maculatus (F.). J Plant Dis Prot 109:193-199

Adedire CO, Akinneye JO (2003) Biological activity of three marigold, Tithonia diversifolia, on cowpea seed bruchids, Callosobruchus maculatus (Coleoptra: Bruchidae). Ann Appl Biol 144:185-189

Adedire CO, Lajide L (1999) Toxicity and oviposition deterency of some plants extracts on cowpea storage bruchids Callosobruchus maculatus (F.). J Plant Dis Prot 106:647-653

Ajele JO, Afolayan A (1992) Purification and characterization of glutathione transferase from Giant African land snail Archachatina marginata. Comp Bioch Phys 103B:47-55

Aruoma OI (2003) Methodological considerations for characterizing potential antioxidant actions of bioactive components in food plants. Mutat Res 524:9-20

Boeke SJ, Van Loon JJA, Van Huis A, Kossou DK, Dicke M (2001) The use of plant materials to protect stored leguminous seeds against seed bettles: a review. Backhuys Publishers, The Netherlands

Boeke SJ, Baumgart IR, Van Loon JJA, Van Huis A, Dicke M, Kossou DK (2004a) Toxicity and repellence of African plants traditionally used for the protection of stored cowpea against Callosobruchus maculatus. J Stored Products Res 40:423-438

Boeke SJ, Barnaud C, Van Loon JJA, Kossou DK, Van Huis A, Dicke M (2004b) Efficacy of plant extracts against the cowpea bettle, Callosobruchus maculatus. Inter J Pest Manag 50(4):251-258

Bradford MM (1976) A rapid and sensitive method for the quantitation of microgram quantities of protein utilising the principle of protein-dye binding. Anal Biochem 72:248-254

Chu YH, Chang CL, Hsu HF (2000) Flavonoids contents of several vegetables and their antioxidant activity. J Sci Food Agric 80:561-566

Coruh N, Sagdicoglu Celep AG, Ozgokce FO (2007a) Antioxidant properties of Prangos ferulacea (L.) Lindl., Chaerophyllum macropodum Boiss. and Heracleum persicum Desf. from Apiaceae family used as food in Eastern Anatolia and their inhibitory effects on glutathione-S-transferase. Food Chem 100:1237-1242

Coruh N, Sagdicoglu Celep AG, Ozgokce FO, Iscan M (2007b) Antioxidant capacities of Gundelia tournefortii L. extracts and inhibition on glutathione-S-transferase activity. Food Chem 100:1249-1253

Despres L, David JP, Gallet C (2007) The evolutionary ecology of insect resistance to plant chemicals. Trends Ecol Evol 22(6):298-307

Dixon M, Webb EC (1979) Enzymes, 3rd edn. Longmans \& Green, New York

Enayati AA, Ranson H, Hemingway J (2005) Insect glutathione transferases and insecticide resistance. Insect Mol Biol 14: 3-8

Fakae BB, Campbell AM, Barrett J, Scott IM, Teesdale-Spittle PH, Liebau E, Brophy PM (2000) Inhibition of glutathione S-transferases (GSTs) from parasitic nematodes by extracts from traditional Nigerian medicinal plants. Phyto Res 14:630-634

Francis F, Vanhaelen N, Haubruge E (2005) Glutathione S-transferases in the adaptation to plant secondary metabolites in the Myzus persicae Aphid. Arc Insect Biochem Physiol 8:166-174

Gyamfi AM, Ohtani II, Shinno E, Aniya Y (2004) Inhibition of glutathione S-transferases by thonningianin $\mathrm{A}$, isolated from the African medicinal herb, Thonningia sanguinea, in vitro. Food Chem Toxicol 42:1401-1408 
Habig WH, Pabst MJ, Jakoby WB (1974) Glutathione S-transferases the first enzymatic step in mercapturic acid formation. J Biol Chem 249:7130-7139

Haubruge E, Amichot M (1995) Les mecanismes responsables de la resisitance aux insecticides chez les insects et les acariens. BASE 2:161-174

Jackai LEN, Adalla, CB (1997) Pest management practice in cowpea. In: Singh BB, MohanRaj DR, Dashielle KE, Jackai LEN (eds) Advances in cowpea research, pp 240-258. Co-publication of Internation Instuitute of Tropical Agriculture (IITA) and Japan International Research Centre for Agricultural Science

Kawabata K, Yamamoto T, Hara A, Shimizu M, Yamada Y, Matsunaga K (2000) Modifying effects of ferulic acid on azoxymethane-induced colon carcinogenesis in F344 rats. Cancer Lett 157(1):15-21

Kolawole AO, Ajele JO (2004) Substrate specifities and inhibition studies on African cat-fish (Clarias gariepinus) liver glutathione s-transferases. Global J Pure Appl Sci 10(1):179-182

Lale NES (1992) A laboratory study of the comparative toxicity of products from the three species of the Maize weevil. Postharvest Biol Technol 2:612-664

Ngbede J, Yakubu RA, Nyam DA (2008) Phytochemical Screening for Active compounds in Canarium schweinfurthii (Atile) leaves from Jos North, Plateau State, Nigeria. Res J Biol Sci 3(9): 1076-1078

Pulido R, Bravo L, Saura-Calixto F (2000) Antioxidant activity of dietary polyphenols as determined by a modified ferric reducing/ antioxidant power assay. J Agric Food Chem 48:3396-3402
Singleton VL, Orthofer R, Lamuela-Raventos RM (1999) Analysis of total phenols and other oxidation substrates and antioxidants by means of Folin-Ciocalteu reagent. Methods Enzymol 299:152-178

Skerget M, Kotnik P, Hadolin M, Hras A, Simonic M, Knez Z (2005) Phenols, proanthocyanidins, flavones and flavonols in some plant materials and their antioxidant activities. Food Chem 89(2): $191-198$

Sofowora A (1993) Phytochemical screening of medicinal plants and traditional medicine in Africa, 2nd edn. Spectrum Books Limited, Nigeria, pp 150-156

Sugiyama Y, Stolz A, Sugimoto M, Kaplowitz N (1984) Evidence for a common high affinity binding site on glutathione S-transferase B for litholic acid and bilirubin. J Lipid Res 25:1177-1183

Valko M, Rhodes CJ, Moncol J, Izakovic M, Mazur M (2006) Free radicals, metals and antioxidants in oxidative stress-induced cancer. Chemico-Biol Interact 160:1-40

Yu SJ (1996) Insect glutathione S-transferases. Zool Stud 35:9-19

Zanden JJV, Geraets L, Wortelboer HM, Bladeren PJV, Rietjens IMCM, Cnubben NHP (2004) Structural requirements for the flavonoid-mediated modulation of glutathione S- transferase P1-1 and GS-X pump activity in MCF7 breast cancer cells. Biochem Pharmacol 67:1607-1617

Zhang X, Cheng X, Wang C, Xue Z, Yang L, Xi Z (2007) Studies of interaction between plant secondary metabolites and glutathione transferase using fluorescence quenching method. Indian $\mathrm{J}$ Biochem Biophy 44:101-105 